\section{The role of financial media in share repurchases}

\author{
Cristian A. Pinto-Gutiérrez \\ Universidad del Desarrollo, School of Economics and Business, \\ Santiago, Chile
}

\begin{abstract}
Purpose - This paper examines the impact that financial media coverage has on share repurchase outcomes in the U.S.

Design/methodology/approach - I perform regression analysis to examine how the volume of firm-specific news articles about the announcements relates to firms' decisions to actually repurchase shares following those announcements. I also examine the role of media in the firms' long-term post-announcements stock performances. To alleviate concerns about confounding effects that can simultaneously drive both the volume of news articles and share repurchase outcomes, I use an instrumental variable approach.
\end{abstract}

Findings - The results show that the levels of firm-specific media coverage at the time of repurchase announcements are negatively related to firms' actual repurchases following the announcements. Furthermore, the evidence shows that twelve months following repurchase announcements, the highest cumulative abnormal returns correspond to the firms with the least media coverage. These results suggest that only those firms that do not attract sufficient investor attention to the announcements follow through on their repurchase programs.

Originality/value - This paper augments the literature on behavioral finance by introducing and testing a firm-specific measure of investor attention by employing a newly available database of news articles from a news analytics provider. The paper also contributes to the sparse literature that examines the effects of investor attention on corporate events.

Keywords - Investor attention; share repurchases; news analytics; media coverage.
Received on

11/13/2015

Approved on

07/14/2016

Responsible editor:

Prof. Dr. Andre Taue Saito

Evaluation process:

Double Blind Review

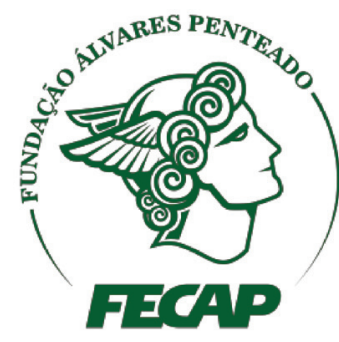

Review of Business Management 


\section{Introduction}

The open-market share repurchase ${ }^{1}$ payout method is the most common way managers distribute cash to shareholders. With this method, a firm will usually announce in advance its intentions to repurchase a fraction of the companies' outstanding shares in the open market over a number of months. This announcement does not commit the firm to actually follow through with the program and repurchase shares; in fact, in many cases, firms do not complete repurchase programs, and many firms do not repurchase at all (e.g., Oded, 2005; Yook, 2010). The literature generally uses the term managerial "cheap talk" to refer to share repurchase announcements that are not completed.

In this paper, I use recent advances in news analytics to examine the effect of investor attention on share repurchase outcomes and explain managerial "cheap talk." To measure investor attention, I calculate the amount of firmspecific news items in a recently developed news analytics product: The Thomson Reuters News Analytics (TRNA). TRNA is a machine readable service that contains all news that Reuters or the represented companies themselves (through newswire services) publish from January 2003 onwards. The advantage of this data set is that it contains news articles and press releases that have appeared on the screens of traders, and therefore, is a direct source of data to proxy for the attention of professional investors.

I begin my investigation by examining how the degree of firm-specific investor attention on the announcement relates to a firm's decision to actually repurchase shares following the announcements. I hypothesize that for firms with high levels of investor attention, the mere announcements of repurchases will be enough to correct the undervaluation, and firms will not need to actually repurchase shares. This argument is based on Vermaelen's (1984) model of signaling where managers of undervalued firms will convey the inside information using share repurchases as a signaling mechanism. I argue, however, that repurchase announcements will only work as a signaling mechanism as long as investors are attentive to companies' information. Indeed, after controlling for other factors, I find that the fraction of shares a firm actually repurchases after the announcement is negatively associated with the volume of news articles about the announcement. Consistent with my hypothesis, this result indicates that firms that attract high levels of investor attention to their announcements do not repurchase a large fraction of their shares.

This result is contrasting to those of Bhattacharya and Jacobsen (2015). The authors argue that firms with low numbers of financial analysts, low ratios of institutional ownership, and low levels of advertising expenditures are the most undervalued firms. Then the authors propose that these highly undervalued firms will attract sufficient attention from speculators who will trade away mispricing so that they will not need to actually materialize the buybacks. Prior studies, however, have used the same set of variables used by Bhattacharya and Jacobsen as proxy for mispricing, as proxies for levels of investor attention (e.g., King \& Segal 2009; Lehavy \& Sloan 2008; Madsen \& Niessner, 2015). Thus, Bhattacharya and Jacobsen's (2015) results seem to suggest that ex-ante investor attention is positively related to the fraction of shares a firm actually repurchases after the announcement. This result contrasts with my findings when I use media coverage as proxy for investor attention.

I follow by performing a robustness check of my previous finding. Because a number of unobservable firm characteristics can simultaneously drive both the volume of news articles and repurchase outcomes, I use an instrumental variable (IV) approach with two instruments to mitigate endogeneity concerns. The first instrument uses variations in firms' advertising expenditures. Empirical evidence documents that 
firms' advertising expenditures are strongly and positively related to the media coverage firms receive (e.g., Reuter \& Zitzewitz, 2006; Gurun $\&$ Butler, 2012). The second instrument uses a measure of the degree of distraction of media outlets, because some exogenous events may have shifted overall attention away from the firm that is announcing share repurchases. To identify distracting events, I use a measure developed by Eisensee and Strömberg (2007) that is based on the number of minutes that U.S. evening news broadcasts devote to the first three news segments in a day. Financial scholars have used this measure before. For instance, Peress and Schmidt (2014) use it to proxy for general investor attention to financial markets. Meanwhile, Liu, Sherman, and Zhang (2014) use a similar measure also as an instrumental variable for media coverage. Overall, my previous findings remain robust after I use the IV approach to control for endogeneity concerns.

Next, I reexamine the effects of media coverage on firms' actual repurchase activities, but now control for the effects of the quality of the information available on their stocks and the magnitude of their stock mispricing. Specifically, I re-estimate the role of investor attention with two additional interaction terms between media coverage and two proxies for mispricing, the numbers of sophisticated (institutional) investors who hold the stocks and the number of analysts who are following the firms. I argue that firms with high-quality information available on their stocks and in the hands of sophisticated investors will not have economic reasons to actually repurchase shares, especially if they attract sufficient investors' attention to the announcements. I expect that the negative relationship between investor attention on the announcements and share repurchase activities will be most pronounced among stocks that are priced most efficiently. I find that the negative relationship between media coverage and actual share repurchase actions after the announcements is more pronounced among stocks that are less likely to be mispriced (stocks from firms with high institutional investor ownership and high analysts coverage). Overall, this evidence suggests that managers of firms with high media coverage and low potential mispricing are less committed to complete their repurchase programs and their announcements are more likely to be "cheap talk."

Finally, I also examine the role of media in the firms' long-term post-announcements stock performances. If companies that have low investor attention on the announcements are the only firms that actually repurchase shares, then I expect their long-term positive stock performances to be the highest among these same announcers, especially if these firms are also the firms with the severest undervaluation. I find that firms with the lowest media coverage on the announcements correspond to the firms with the highest cumulative abnormal returns three, six, and 12 months following the events. These results suggest that high media coverage may imply both more efficient market reactions at the time of the announcements and lower undervaluation prior to the announcements, resulting in a negative association between media coverage and postannouncement price drifts. These results are also consistent with Yook (2010) who finds that only firms that actually repurchased shares experienced significant long-term abnormal returns.

Although scholars have explored financial media as a potential determinant of the success of other corporate events, and despite the fact that share repurchases are among the corporate events that receive the most business media attention, ${ }^{2}$ the role that media and, more broadly, investor attention, have on share repurchase activity has remained largely unexplored in the financial literature. Here lies the main contribution of this paper to the financial literature. I also contribute to the growing literature on the media and its influence in stock prices, however, in contrast to previous literature that uses news articles published in major newspapers (e.g., Tetlock, 2007; Tetlock, Saar-Tsechansky, \& Macskassy, 
2008; Fang \& Peress, 2009), I focus on firmspecific public news that professional traders receive electronically in real time.

I structure the remainder of the paper as follows. Section 2 develops the hypotheses. Section 3 introduces the empirical methodology. Section 4 presents the data sets I use in the empirical analysis. Section 5 establishes the key empirical results. The last section contains a summary and concluding remarks.

\section{Hypotheses development}

Undervaluation appears to be one of the most important factors in firms' decisions to repurchase shares. Peyer and Vermaelen (2009) show that in nearly 50 percent of the cases, firms explain their motivations for repurchases by mentioning "undervaluation" and "best use of money" in their press releases. Furthermore, Survey evidence by Brav, Graham, Harvey, and Michaely (2005) report that 86 percent of the respondents find the "market price" of their stock is an important or a very important factor in their companies' repurchasing decisions ("market price" meaning "if our stock is a good investment relative to its true value").

Vermaelen (1984) took the first theoretical approach to model share repurchases as the result of stock undervaluation. In his model, managers of undervalued firms, who are trying to maximize the value of their stock options and prevent takeover bids, will convey the inside information using share repurchases as a signaling mechanism. According to the signaling theory, two types of signals are available: costly and costless signals. An early example of costly signaling in capital markets was provided by Ross (1977); Ross showed how managers can use debt as a signal to separate profitable from insolvent companies, resulting in a positive relationship between a firm's value and leverage. Costless, non-binding signals (also referred to in the literature as "cheap talk") can also be credible signals, and thus, they have valuation effects (e.g., Crawford \& Sobel, 1982; and Almazan, Banerji, \& De Motta, 2008). Open market share repurchase announcements may fall into this category of managerial "cheap talk." This categorization is appropriate because unlike other corporate events, share repurchase announcements are non-binding commitments. Firms are free to decide whether and how many shares, if any, to actually repurchase after the announcements.

This signaling hypothesis is the focus of my investigation in this paper. I argue that repurchase announcements will only work as costless signaling mechanisms as long as investors are attentive to companies' information. Several studies have demonstrated that investors are attention constrained and suggest that investors' limited attention has important consequences in financial markets (see, for example, Merton, 1987; Barber \& Odean, 2008; Fang \& Peress, 2009). In this article, I test this relationship between share repurchase announcements and investors' attention. I hypothesize that for firms with high levels of investor attention, the mere announcements of repurchases will be enough to correct the undervaluation, and firms will not need to actually repurchase shares. Firms that fail to attract sufficient investor attention on the repurchase announcements, however, will have to use costly signals and actually repurchase a relatively large amount of their shares after the announcements to correct the perceived undervaluation. The following is the first hypothesis in this paper.

\section{H1: High investor attention (measured by the volume of firm-specific news articles) at the time of share repurchase announcements is negatively related to actual repurchase activity following the announcements.}

Moreover, I test the hypothesis that firms with low investor attention may also be the firms with the highest undervaluation, and 
thus will have economic reasons to use costly signals. In particular, I examine the effect of media coverage in relationship to other proxies for mispricing. I argue that firms with highquality information available on their stocks and in the hands of sophisticated investors will not use costly signals (actual repurchases), especially if they attract sufficient investors' attention to the announcements. I hypothesize that the negative relationship between investor attention on the announcements and share repurchase activities (Hypothesis 1) will be most pronounced among stocks that are priced most efficiently (stocks from firms with high institutional investor ownership and high analysts' coverage). The following is the second hypothesis:

H2: The magnitude of the negative relationship between investor attention and actual repurchase activity is most pronounced for stocks with small mispricing.

Now, if only these companies that have low investor attention on the announcements are the firms that actually repurchase shares (Hypothesis 1), I expect their long-term positive stock performances to be the highest among these same announcers, especially if these firms are also the firms with the severest undervaluation (Hypothesis 2). These expectations lead to the third hypothesis.

H3: The magnitude of the positive long-term performance of share repurchases is negatively related to the degree of investor attention at the time of the announcements.

\section{Methodology}

I begin by examining whether firms' actual repurchase activities after the announcements are functions of the volume of news articles about the announcements. I hypothesize that media coverage is negatively related to actual repurchase activity (hypothesis 1 ). To test this hypothesis, I use the following model:

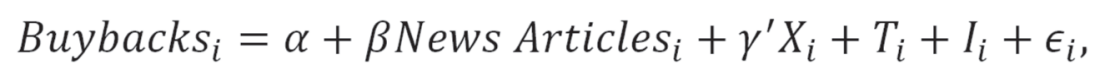

where Buybacks $_{i}$ is a variable that takes two definitions. In the first two definitions, the dependent variable uses the percentage of actual repurchases. To construct this variable, I sum the dollar amount a firm repurchased from the announcement quarter $t$ to quarter $t+1$. Then, I divide the results by the firm's market equity in the quarter immediately prior to the announcement $t$-1. I also consider repurchases that occur in the first year following the announcements. For this definition, I sum repurchases from quarter to quarter $t+3$, and divide the results by a firm's market equity in quarter $t-1$. Because share buybacks are non-binding commitments that offer managers the flexibility of choosing when to acquire the shares and how many shares to actually buy back, the decision of whether to repurchase may be different from the decision of how much to repurchase, once managers have decided to do so. In this situation, the appropriate empirical model to estimate equation (1) should be a Tobit model 
The next two definitions for Buybacks are in the form of binary variables. The first binary variable equals one if firm i registers a share repurchase from quarter $t$ to quarter $t+1$ of more than one percent of its market equity, and equals zero otherwise. In the second definition, the binary variable equals one if the firm registers a share repurchase of more than one percent of its market equity from quarter $t$ to quarter $t+3$. Here, the empirical model I employ is a Logit model.

To define the depended variable, Buybacks, I follow previous literature (e.g., Yook, 2010; Nguyen, 2013; Bhattacharya \& Jacobsen, 2015) and use the Compustat item, Purchase of Common and Preferred Stock (PRSTKCY in the Compustat database). Early literature noted that these data overstate stock repurchases because they include Dutch auctions, privately negotiated deals, selftender offers, and conversions of other securities into stocks (e.g., Stephens \& Weisbach, 1998; Jagannathan, Stephens, \& Weisbach, 2000). Therefore, to mitigate these measurement errors and as prior literature suggests, I subtract from the PRSTKCY any decrease in the value of preferred stocks (at redemption or carrying values, PSTKRQ or PSTKQ items in the Compustat database, respectively). Then, I calculate the dollar amount of share repurchases by summing the quarterly results and dividing them by each firm's market equity the quarter immediately prior to the announcement. I Winsorize the results at the upper and lower one percent levels to ensure that extreme values on the dependent variable do not drive the results. This approach is the standard procedure the scholars use in the finance literature to minimize the influence of extreme outliers.

The buyback calculation results are summarized in Table 1. Panel A of Table 1 summarizes the results for the full sample of share repurchases from 2003 to 2012. Panel B of Table 1 summarizes the results for the sample with TRNA data that I use in this study. For the latest sample, the value of total repurchases during the first two quarters and in the first year following the announcements, divided by the market equities, resulted in averages of 2.7 percent and 5.1 percent, respectively. The table also shows that only 69.8 percent and 85.2 percent, respectively, of the firms do repurchase more than one percent of the value of their market equities during the first two quarters or the first year following the announcements. 


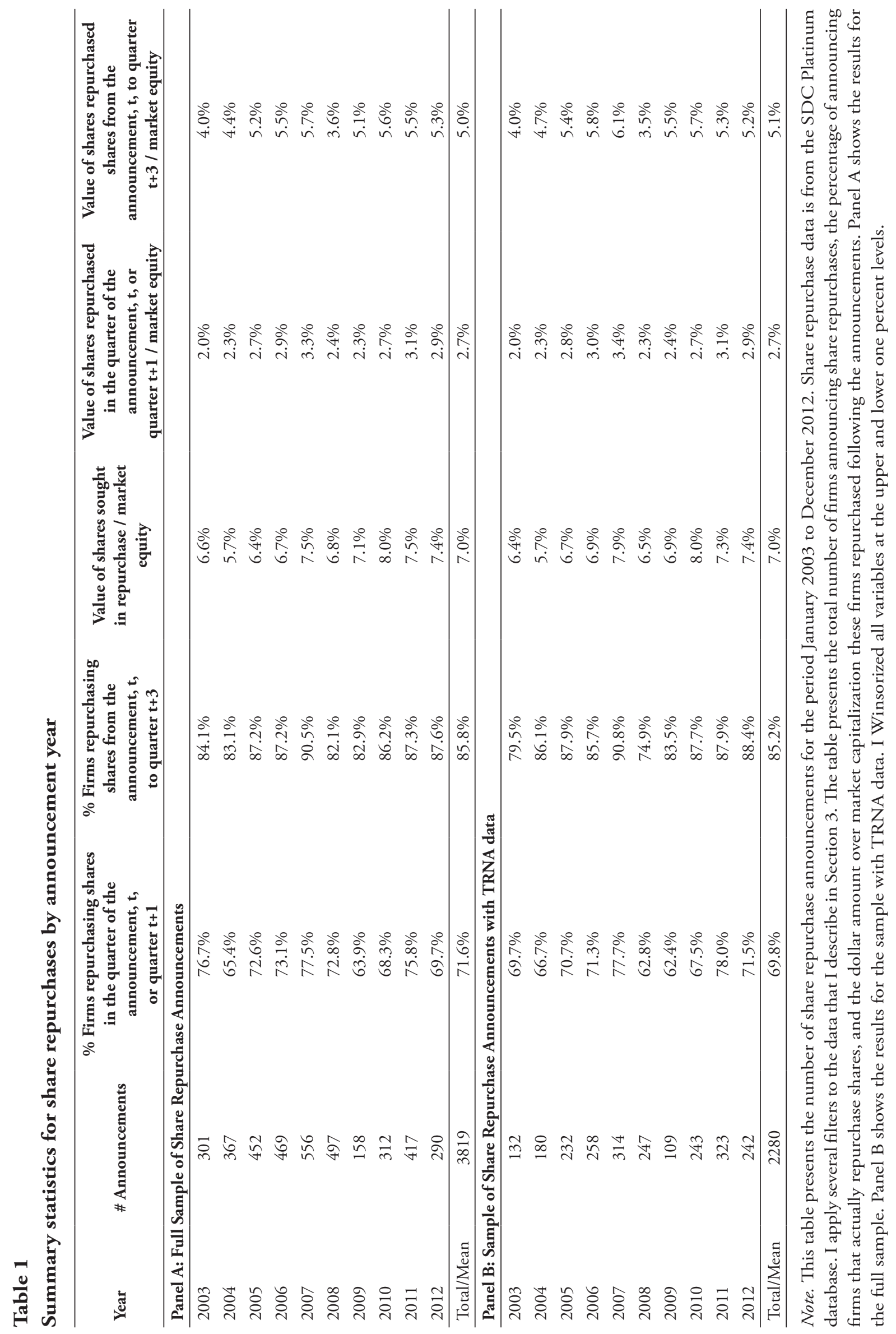


The variable News Articles $i$ in equation (1) is the number of news articles for firm 90 days before the announcements and ten days after the announcements. Because I want to ensure that extreme values on the key independent variable do not drive the results of my analysis, I Winsorize news article volumes at the upper and lower one percent levels. The vector $X_{i}$ contains firms' characteristics that control for key factors that may also affect repurchase decisions. I control for the following firm characteristics: market-to-book ratio, firm's return from the past 12 months, stock volatility for the preceding 24 months, natural log of total assets, natural log of market equity, debt to assets ratio (leverage), return on assets (ROA), Altman Z-score, capital expenditures (CAPEX) to assets, and dividends to income. I calculate all firm-level control variables on a quarterly basis using the most recent quarter prior to the repurchase announcement. I include in all regressions both year ( $\mathrm{T}$ ) and industry (I) fixed-effects. These variables allow for a different intercept for each industry and year. Throughout, I do not report the coefficients of these variables. To calculate industry fixed-effects, I use the FamaFrench 49 industry classification. I also Winsorize all control variables at the upper and lower one percent levels.

Next, I examine whether companies with low levels of mispricing will repurchase even fewer shares than otherwise, when media coverage increases. I hypothesize that media coverage will play a large incremental role in repurchase activities of firms with small mispricing (hypothesis 2). To test this hypothesis, I use the following model:

$$
\begin{aligned}
& \text { Buybacks }_{i}=\alpha+\beta_{1} \text { News Articles }_{i}+\beta_{2} \text { Mispricing }_{i}+ \\
& \theta^{\prime} \text { Interaction terms }+\gamma^{\prime} X_{i}+T+I_{i}+\epsilon_{i},
\end{aligned}
$$

where I define Buybacks $i$ and News Articles $i$ as in equation (1), and Mispricing r $_{i}$ represents two proxies for potential mispricing: the number of analysts who are following the firm and the number of institutional owners who hold the stock, as reported on Form 13F filed with the Securities and Exchange Commission (SEC). The variables of interest in this model are the interaction terms between the number of news articles and the mispricing proxies. The interaction terms allow me to analyze how firms' decisions to repurchase may vary in relation to the firms' degrees of mispricing and their media coverage. The vector $X_{i}$ includes control variables. I also control for both year and firm fixed-effects.

Finally, I hypothesize that the long-term positive stock performances will be the highest among companies that have low investor attention on the announcements (hypothesis 3). To measure long-run performances of the announcing firms, I calculate long-term stock returns over different horizons for announcements classified into two categories according to the volumes of news stories around the announcement dates. To adjust for expected returns, I use multiple approaches. First, I calculate portfolio-matched buy-and-hold abnormal returns (BHARs) for three, six, and 12 months after the offering dates. Second, I compute cumulative abnormal returns (CARs), which are similar to BHARs, but involve summing returns rather than compounding (multiplying). ${ }^{3}$ To obtain the BHARs and CARs, I calculate monthly returns over the different horizons and then subtract the returns of a benchmark portfolio over the same periods. The benchmark portfolio I use corresponds to the Fama and French (1993) valueweighted size/book-to-market (BM) quintile portfolio. To obtain the adjusted returns, I match each firm to one of the 25 corresponding size/BM portfolios at the beginning of the announcement quarter using the size/BM breakpoints from Professor Kenneth French's website.

Finally, I use the calendar-time regression approach. Fama (1998); Mitchell and Stafford 
(2000); Brav, Geczy, and Gompers (2000), among others, recommend applying the calendar month portfolio approach to mitigate the problems of correlation of returns across events when calculating the expected returns in long-term abnormal returns.

\section{Data}

I start by collecting all company-specific news articles from Thomson Reuters News Analytics (TRNA). TRNA is a comprehensive archive that contains all news that Reuters News or the companies themselves (via newswire services such as PR Newswire and Business Wire, among others) publish. Sinha (2011), Kyle et al. (2012), and Cahan, Chen, and Nguyen (2013) describe the dataset in detail. For this study, the sample covers all news articles Reuters sent to its clients from January 2003 through December 2012.

I only consider news articles for U.S. common stocks listed in the New York Stock Exchange (NYSE), the American Stock Exchange (Amex), and the Nasdaq National Market (NASDAQ). In total, TRNA contains about 1.9 million news items for the stocks listed on these exchanges from January 2003 to December 2012. The average number of firms the database covered during this period was 3,820.

I follow Kyle et al. (2012) by applying several filters to include only the most "attentiongrabbing" news stories. I remove all one-line alert messages that Thomson Reuters usually sends out before important news articles appear in full. I exclude updates and corrections because they simply provide additional detail about original articles. I also exclude news items linked to more than one article in the sample (wrap-up articles), to make sure that this information had not already appeared in the sample. I then merge the TRNA dataset with stock prices from the Center of Research in Security Prices (CRSP) and firms' financial information from COMPUSTAT. I include only common stocks. After imposing these filters and merging the databases, I identify 764,680 news articles from January 2003 to December 2012 on 3,392 companies.

Next, I collect data on share repurchases from the Securities Data Corporation (SDC) database. SDC provides the initial board of directors' authorization dates of repurchase programs. I use this date as the announcement date. I exclude repurchase announcements that identify acquisitions and the offset of the dilution effects from both employee stock options and convertible debt as the motives for repurchases. In line with the earlier literature on buybacks, and to minimize the effects of small stocks, I exclude stocks with prices lower than $\$ 5$ the day before the repurchase announcements. Finally, also to conform to the previous literature, and minimize the influence of regulatory issues, I exclude share repurchase announcements by financials (SIC code 6000-6999) and utilities (SIC code 49004999). After imposing these filters and merging the resulting repurchases with the TRNA, CRSP, and COMPUSTAT databases, I identify 2,280 buyback announcements from January 2003 to December 2012 by 1,041 companies.

Table 2 provides descriptive statistics for the final sample; these figures include news article data, repurchase details, and the firms' characteristics. An average announcing firm appears in 11.5 news articles during the period from 90 days prior to and ten days following the announcement date. The average announced value of shares sought in a repurchase over the market equity of a firm is 7.3 percent. The actual value of repurchased shares over the market equity in the quarter of, or quarter following the announcement, is 2.8 percent, and the actual value of shares repurchased over market equity within one year following the announcement is 5.2 percent. 
Table 2

Summary statistics for key variables

\begin{tabular}{|c|c|c|c|c|c|c|c|}
\hline & $\mathbf{N}$ & Mean & Min & $\operatorname{Max}$ & SD & Skewness & Kurtosis \\
\hline \multicolumn{8}{|l|}{ TRNA: } \\
\hline News Articles $(-90,+10)$ & 2280 & 11.5 & 0.0 & 110.0 & 15.8 & 3.7 & 20.6 \\
\hline \multicolumn{8}{|l|}{ Buybacks characteristics: } \\
\hline $\operatorname{CAR}(-1,1)$ & 2280 & 1.1 & -21.0 & 19.0 & 5.8 & -0.4 & 6.3 \\
\hline Announced Repurchase Size (\$Million) & 2268 & 522.3 & 1.0 & 8500.0 & 1245.0 & 4.4 & 24.4 \\
\hline $\begin{array}{l}\text { Shares Sought in Repurchase / } \\
\text { Share Outstanding (\%) }\end{array}$ & 2245 & 7.3 & 0.9 & 27.5 & 5.0 & 1.6 & 6.1 \\
\hline $\begin{array}{l}\text { Value Sought in Repurchase / } \\
\text { Market Equity (\%) }\end{array}$ & 2168 & 7.1 & 0.8 & 26.4 & 4.8 & 1.5 & 5.9 \\
\hline $\begin{array}{l}\text { Value Repurchased Quarter } 2 / \\
\text { Market Equity (\%) }\end{array}$ & 2128 & 2.8 & 0.0 & 14.1 & 2.9 & 1.7 & 6.0 \\
\hline $\begin{array}{l}\text { Value Repurchased Quarter } 4 \text { / } \\
\text { Market Equity (\%) }\end{array}$ & 2099 & 5.2 & 0.0 & 23.7 & 4.6 & 1.5 & 5.6 \\
\hline $\begin{array}{l}\text { Total Shares Repurchased / } \\
\text { Shares Sought in Repurchase (\%) }\end{array}$ & 1896 & 74.7 & 2.0 & 200.0 & 37.7 & 0.3 & 3.6 \\
\hline \multicolumn{8}{|l|}{ Firms characteristics: } \\
\hline Ln (Market Equity) & 2180 & 7.6 & 2.3 & 12.7 & 1.8 & 0.1 & 2.9 \\
\hline Ln (Assets) & 2183 & 7.3 & 3.4 & 11.8 & 1.8 & 0.1 & 2.6 \\
\hline Leverage & 2101 & 0.2 & 0.0 & 0.7 & 0.2 & 0.9 & 3.1 \\
\hline $\mathrm{ROA}$ & 2174 & 0.1 & -0.1 & 0.3 & 0.1 & 0.7 & 6.0 \\
\hline CAPEX to Assets & 2181 & 0.0 & 0.0 & 0.2 & 0.0 & 2.4 & 9.8 \\
\hline Cash to Assets & 2183 & 0.2 & 0.0 & 0.7 & 0.2 & 1.2 & 3.5 \\
\hline Market-to-Book Ratio & 2166 & 3.4 & 0.6 & 30.3 & 4.0 & 4.5 & 27.1 \\
\hline Returns Past 12 Months & 2224 & 0.2 & -0.6 & 1.9 & 0.4 & 1.4 & 6.0 \\
\hline Stock Volatility 24 Months & 2162 & 0.1 & 0.0 & 0.3 & 0.0 & 1.4 & 5.3 \\
\hline Institutional Ownership Ratio & 2280 & 0.8 & 0.1 & 1.2 & 0.2 & -1.0 & 3.9 \\
\hline Ln (1+Number of Analysts) & 2280 & 2.2 & 0.0 & 3.7 & 0.9 & -0.9 & 3.2 \\
\hline Dividends / income & 2170 & 0.0 & 0.0 & 0.4 & 0.1 & 2.6 & 11.4 \\
\hline Age (Since IPO) & 2183 & 20.5 & 1.0 & 41.0 & 11.3 & 0.2 & 1.8 \\
\hline
\end{tabular}

Note. This table gives descriptive statistics for dependent and independent variables. News articles are taken from the Thomson Reuters News Analytics for the period January 2003 to December 2012. Data on firms' characteristics is collected from COMPUSTAT. Share repurchase announcements are taken from the SDC Platinum database. The table presents the number of observations $(N)$, mean, minimum, maximum, standard deviation, skewness, and kurtosis. I define all variables in the Appendix. 


\section{Empirical results}

In this section, I present empirical evidence of the effects that firm-specific investor attention at the time of share repurchase announcements, as measured by the degree of media coverage, has on (i) the firms' actual buyback actions following the announcements, and (ii) the long-term stock performances of announcing firms. In all these tests, I base my measure of investor attention on the number of news articles written about the firm in the 90 days preceding and ten days following the share repurchase announcements. I use 90 days prior to the announcements because I want to measure the degree of investor attention at the moment firms announce their repurchase programs. I also use the day of and ten days after the announcements to include the attention attracted by announcements themselves. ${ }^{4}$

\section{I Investor attention and actual buyback activities following the announcements}

Table 3 reports regression results of equation (1), with robust standard errors, for the effects that the total volume of news articles have on actual buyback activity. Models (1) and (2) of Table 3 report the results from the Tobit model. The results show that the volumes of news articles around the announcement dates are negatively related to the market values that firms repurchased. The marginal effect of the variable News Articles for the repurchases during the first two quarters following the announcements is -0.0106 and statistically significant at the five percent level. Similarly, the marginal effect of News Articles for the market values firms repurchased during the first year following the announcements is -0.0198 and statistically significant at the one percent level. To put the economic significance of these coefficients in concrete terms: increasing the number of news articles around the announcement dates by one is associated with a 0.0198 percent decrease in the market value that a firm repurchased in the year following the announcement, or $-\$ 1.84$ million $\left(=-\$ 9,287.2^{*} 1.98 \times 10^{-4}\right)$, with the other variables in the model held constant.

Models (3) and (4) of Table 3 report the results from the Logit model. The results show that high numbers of firm-specific news articles tend to decrease the probability that firms will actually repurchase shares following the announcements. The marginal effect of the variable News Articles for firms' likelihood to repurchase during the first two quarters following the announcements and during the year following the announcements are -0.0014 and -0.0011 , respectively. However, only the last effect is statistically significant.

Overall, the evidence is consistent with hypothesis 1 that investor attention on share repurchase announcements decreases firms' motivation to follow through with their repurchase programs following the announcements. In other words, firms with high media coverage are most likely to "cheap talk" when announcing share repurchases because media coverage and investor attention contribute to the efficiency of the stock market and decrease the economic incentives (high undervaluation) for firms to use costly signals and actually repurchase shares. 
Table 3

Regressions for the decision to repurchase shares after the announcements

Tobit Model

Logit Model

\begin{tabular}{|c|c|c|c|c|}
\hline & $\begin{array}{l}\text { Quarter } t \text { to } \\
\qquad(t+1)\end{array}$ & $\begin{array}{l}\text { Quarter } t \text { to } \\
\qquad(t+3)\end{array}$ & $\begin{array}{c}\text { Quarter } t \text { to } \\
(t+1)\end{array}$ & $\begin{array}{c}\text { Quarter } t \text { to } \\
(t+3)\end{array}$ \\
\hline & $(1)$ & (2) & (3) & (4) \\
\hline \multirow[t]{2}{*}{ News Articles $(-90,+10)$} & $-0.0106^{* *}$ & $-0.0198^{* * *}$ & -0.0014 & $-0.0011^{*}$ \\
\hline & $(0.0047)$ & $(0.0074)$ & $(0.0009)$ & $(0.0006)$ \\
\hline \multicolumn{5}{|l|}{ Controls: } \\
\hline \multirow[t]{2}{*}{ Cash to Assets } & $2.7366^{* * *}$ & $5.9299^{* * *}$ & $0.3034^{* * *}$ & $0.2798^{* * *}$ \\
\hline & $(0.5939)$ & $(0.9105)$ & $(0.0890)$ & $(0.0607)$ \\
\hline \multirow[t]{2}{*}{ Market-to-Book Ratio } & -0.0254 & -0.0261 & 0.0065 & 0.0006 \\
\hline & $(0.0206)$ & $(0.0317)$ & $(0.0058)$ & $(0.0041)$ \\
\hline \multirow[t]{2}{*}{ Returns Past 12 Months } & $0.5332^{* *}$ & $0.9303^{* * *}$ & $0.0621^{* *}$ & $0.0430^{* *}$ \\
\hline & $(0.2148)$ & $(0.3137)$ & $(0.0287)$ & $(0.0202)$ \\
\hline \multirow[t]{2}{*}{ Stock Volatility Past 24 Months } & -1.5395 & -4.7906 & $-1.0677^{* * *}$ & $-0.5398^{* * *}$ \\
\hline & $(2.2002)$ & $(3.1238)$ & $(0.2944)$ & $(0.1774)$ \\
\hline \multirow[t]{2}{*}{ Ln (Assets) } & $0.8462^{* * *}$ & $1.5851^{* * *}$ & $0.0950^{* * *}$ & 0.0374 \\
\hline & $(0.2050)$ & $(0.3158)$ & $(0.0343)$ & $(0.0234)$ \\
\hline \multirow[t]{2}{*}{ Ln (Market Equity) } & $-0.5651^{* * *}$ & $-1.0083^{* * *}$ & -0.0408 & 0.0048 \\
\hline & $(0.1912)$ & $(0.2989)$ & $(0.0333)$ & $(0.0228)$ \\
\hline \multirow[t]{2}{*}{ Leverage } & -0.1184 & $-1.5612^{*}$ & -0.0754 & -0.0167 \\
\hline & $(0.6020)$ & $(0.9475)$ & $(0.1042)$ & $(0.0675)$ \\
\hline \multirow[t]{2}{*}{$\mathrm{ROA}$} & $5.2319^{* * *}$ & $6.2931^{* * *}$ & $0.4947^{* *}$ & 0.1543 \\
\hline & $(1.2531)$ & $(1.8686)$ & $(0.2001)$ & $(0.1443)$ \\
\hline \multirow[t]{2}{*}{ Altman Z-score } & -0.0324 & $-0.0860^{* * *}$ & -0.0042 & -0.0032 \\
\hline & $(0.0230)$ & $(0.0324)$ & $(0.0035)$ & $(0.0023)$ \\
\hline \multirow[t]{2}{*}{ CAPEX to Assets } & 2.2789 & 3.6622 & -0.1886 & 0.2206 \\
\hline & $(2.6417)$ & $(4.0487)$ & $(0.3941)$ & $(0.2605)$ \\
\hline \multirow[t]{2}{*}{ Dividends / Income } & -0.2145 & $-5.3738^{* * *}$ & $-0.3585^{* *}$ & $-0.2886^{* * *}$ \\
\hline & $(1.6280)$ & $(2.0086)$ & $(0.1824)$ & $(0.1082)$ \\
\hline Year Fixed-effects + Intercept & Yes & Yes & Yes & Yes \\
\hline Industry Fixed-effects & Yes & Yes & Yes & Yes \\
\hline $\mathrm{N}$ & 1932 & 1906 & 1958 & 1956 \\
\hline Pseudo-R2 & 0.0201 & 0.0231 & 0.0819 & 0.1211 \\
\hline
\end{tabular}

Note. This table presents the parameter estimates for the following model:

Buyback $_{i}=\alpha+\beta$ News Articles $_{i}+\gamma^{\prime} X_{i}+T_{i}+I_{i}+\epsilon_{i}$

where Buyback ${ }_{i}$ is a variable that takes four definitions. In Models (1) and (2), the dependent variable uses the percentage of actual repurchases. In Models (1), I sum the dollar amount a firm repurchased from the announcement quarter, $t$, to quarter, $t+1$, and divide the results by the firm's market equity in the quarter immediately prior to the announcement. In Models (2), I consider repurchases that occur in the first year following the announcements. For this definition, I sum repurchases from quarter $t$ to quarter $t+3$, and divide the results by the firm's market equity prior to the announcement. In Models (3) and (4), the definitions for Buyback ${ }_{i}$ are in the form of dummy variables. In Models (3), the dummy variable equals one if firm $i$ registers a share repurchase from quarter $t$ to quarter $t+1$ of more than one percent of its market equity, and equals zero otherwise. In Models (4), the variable equals one if the firm registers a repurchase of more than one percent of its market equity from quarter $t$ to quarter $t+3$. The variable News Articles $i$ is the number of news articles for 
firm $i 90$ days prior to and ten days following the announcement. The vector $X_{i}$ contains control variables. Firm-level control variables are calculated on a quarterly basis. I define control variables in Appendix. I also include Fama-French 49 industries fixed-effects $\left(I_{i}\right)$ and year fixed-effects $\left(T_{i}\right)$. Table reports marginal effects at the means. Robust standard errors are in parentheses. ${ }^{*}, * *$, and ${ }^{* * *}$ indicate the marginal effect is significantly different from zero at the $10 \%, 5 \%$, and $1 \%$ significant level, respectively.

For comprehensiveness, I also control for a number of firm characteristics that appear in the existing literature and may also affect actual buyback activities. Consistent with the general economic motives that drive firms' buybacks, such as responding to mispricing or distributing cash, the regressions show that in contrast to other firms, firms with low market-to-book ratios, large cash-to-assets, and low dividends over earnings tend to buy back more stocks in the first year of the programs. Yet, after I control for these previously established economic factors, high media coverage firms repurchase, on average, fewer stocks than expected.

\subsection{Robustness checks: instrumental variable approach}

Next, I use an instrumental variable (IV) approach to address the endogeneity issue relative to the fact that a number of unobservable variables can simultaneously drive both the volume of news articles around the announcement dates and the actual buyback activities. Reverse causality is also possible; companies that expect to buy few shares may attempt to maximize investor attention by generating additional news articles around the dates of repurchase announcements.

Instruments need to represent events that are likely to affect the volume of firm-specific news articles, but that will not directly affect share repurchase outcomes. To represent these events, I employ two instruments. The first instrument uses variations in firms' advertising expenditures. Empirical evidence documents that firms' advertising expenditures are strongly positively related to the media coverage firms receive. For instance, Reuter and Zitzewitz (2006) show that personal finance publications (such as Money Magazine, Kiplinger's Personal Finance, and SmartMoney) are most likely to recommend funds from the mutual fund families that have advertised most frequently within their pages. Gurun and Butler (2012) show that positive media slants about local companies are strongly and positively related to the local advertising budgets of those companies. Therefore, I define advertising as an instrument. This variable equals to the total cost of advertising, media, and promotional expenses as reported in the annual COMPUSTAT item XAD. I measure advertising expenditures at the end of the year prior to the repurchase announcements.

The second instrument uses exogenous distracting events. In particular, I explore episodes of sensational news events that may distract media outlets and affect the media coverage of firms' repurchase announcements. To identify distracting events, I use Eisensee and Strömberg's (2007) news pressure index. The authors define this index as the median number of minutes that evening news broadcasts of the major U.S. networks ( $\mathrm{ABC}, \mathrm{CBS}, \mathrm{NBC}$, and $\mathrm{CNN}$ ) devote to the first three news segments in a day. They argue that this variable is a good indicator of the availability of newsworthy material on a given day.

Peress and Schmidt (2014) use Eisensee and Strömberg's index to examine how individual investors' inattention affects their trading behaviors. They document that investors stop trading when they are distracted. Meanwhile, using the same data base of television news stories Eisensee and Strömberg used (the Vanderbilt University Television News Archive), Liu, Sherman, and Zhang (2014) measure the number of TV news specials on three networks (ABC, NBC, and CBS) and use this measure as an instrumental variable for media coverage (the number of news articles). They show that the number of news special reports is negatively related to the degree of media coverage of IPOs. These studies further support my decision to 
use distraction events reported on TV as an instrument. Therefore, I define the variable, $T V$ news pressure, as an instrument. I construct this measure by summing the daily Eisensee and Strömberg's (2007) indices from ten days prior to and ten days following the share repurchase announcements. I download the news pressure data from Professor David Strömberg's website.

Table 4 reports the results for the instrumental variable approach, using a two-step estimation of the Tobit model. Model (1) of Table 4 reports the first-stage results. As expected, the coefficient of the instrumental variable advertising is positive and significant at the one percent level, while the coefficient on $T V$ news pressure is negative and significant at the ten percent level. More importantly, the result for the F-statistic for weak instruments is 56.59, which largely surpasses the threshold of ten that Stock, Wright, and Yogo (2002) suggested. Models (2) and (3) of Table 4 report the second-stage results. The marginal effect of the variable News Articles for the repurchases during the first two quarters following the announcements is -0.0413 and statistically significant at the ten percent level. Similarly, the marginal effect of News Articles for the market values firms repurchased during the first year following the announcements is -0.0627 and statistically significant at the ten percent level. These results suggest that the negative relationship I reported earlier between the volume of news articles around the announcement dates and companies' actual share repurchase actions, although it loses some of its statistical significance, retains the same sign after I control for potential endogeneity problems. ${ }^{5}$

Table 4

Instrumental variable Tobit regressions for the decision to repurchase shares after the announcements

\begin{tabular}{|c|c|c|c|}
\hline & \multirow[t]{2}{*}{$\begin{array}{l}\text { First Stage: } \\
\text { News Articles }\end{array}$} & \multicolumn{2}{|c|}{$\begin{array}{c}\text { Second Stage (Tobit): } \\
\text { Buybacks }\end{array}$} \\
\hline & & $\begin{array}{l}\text { Quarter } t \text { to } \\
\text { quarter } t+1\end{array}$ & $\begin{array}{l}\text { Quarter } t \text { to } \\
\text { quarter } t+3\end{array}$ \\
\hline & (1) & (2) & (3) \\
\hline News Articles $(-90,+10)$ & & $-0.0413^{*}$ & $-0.0627^{*}$ \\
\hline (Instrumented) & & $(0.0219)$ & $(0.0334)$ \\
\hline \multicolumn{4}{|l|}{ Instruments: } \\
\hline \multirow[t]{2}{*}{ Advertising } & $0.0085^{* * *}$ & & \\
\hline & (0.0008) & & \\
\hline \multirow[t]{2}{*}{ TV News Pressure } & $-0.0339 *$ & & \\
\hline & $(0.0176)$ & & \\
\hline \multicolumn{4}{|l|}{ Controls: } \\
\hline \multirow[t]{2}{*}{ Cash to Assets } & 0.4346 & $2.7492^{* * *}$ & $5.9360^{* * *}$ \\
\hline & $(2.3693)$ & $(0.5631)$ & $(0.8502)$ \\
\hline \multirow[t]{2}{*}{ Market-to-Book Ratio } & 0.1733 & -0.0171 & -0.0175 \\
\hline & $(0.1084)$ & $(0.0259)$ & $(0.0392)$ \\
\hline \multirow[t]{2}{*}{ Returns Past 12 Months } & 0.0147 & $0.5143^{* * *}$ & $0.9170^{* * *}$ \\
\hline & $(0.8212)$ & $(0.1948)$ & $(0.2961)$ \\
\hline \multirow[t]{2}{*}{ Stock Volatility Past 24 Months } & $31.2988^{* * *}$ & -0.5126 & -3.4203 \\
\hline & $(8.1904)$ & $(2.0743)$ & $(3.1222)$ \\
\hline \multirow[t]{2}{*}{ Ln (Assets) } & $2.6102^{* * *}$ & $0.9375^{* * *}$ & $1.7049^{* * *}$ \\
\hline & $(0.8365)$ & $(0.2098)$ & $(0.3179)$ \\
\hline
\end{tabular}




\begin{tabular}{|c|c|c|c|}
\hline & \multirow[t]{2}{*}{$\begin{array}{l}\text { First Stage: } \\
\text { News Articles }\end{array}$} & \multicolumn{2}{|c|}{$\begin{array}{c}\text { Second Stage (Tobit): } \\
\text { Buybacks }\end{array}$} \\
\hline & & $\begin{array}{l}\text { Quarter } t \text { to } \\
\text { quarter } t+1\end{array}$ & $\begin{array}{l}\text { Quarter } t \text { to } \\
\text { quarter } t+3\end{array}$ \\
\hline & $(1)$ & $(2)$ & (3) \\
\hline \multirow[t]{2}{*}{ Ln (Market Equity) } & $2.4233^{* * *}$ & $-0.4829^{* *}$ & $-0.8817^{* * *}$ \\
\hline & $(0.8147)$ & $(0.2008)$ & $(0.3042)$ \\
\hline \multirow[t]{2}{*}{ Leverage } & $-11.2972^{* * *}$ & -0.4930 & $-2.0832^{* *}$ \\
\hline & $(2.6447)$ & $(0.6870)$ & $(1.0452)$ \\
\hline \multirow[t]{2}{*}{ ROA } & 0.6084 & $5.0965^{* * *}$ & $6.1358^{* * *}$ \\
\hline & $(5.4651)$ & $(1.3007)$ & $(1.9674)$ \\
\hline \multirow[t]{2}{*}{ Altman Z-score } & 0.0037 & -0.0328 & $-0.0868^{* * *}$ \\
\hline & $(0.0917)$ & $(0.0219)$ & $(0.0330)$ \\
\hline \multirow[t]{2}{*}{ CAPEX to Assets } & -8.6697 & 1.8918 & 2.8692 \\
\hline & $(11.2616)$ & $(2.6718)$ & $(4.0902)$ \\
\hline \multirow[t]{2}{*}{ Dividends / Income } & $17.0748^{* * *}$ & 0.4893 & $-4.5490^{* *}$ \\
\hline & $(5.1178)$ & $(1.3049)$ & $(1.9762)$ \\
\hline Year Fixed-effects + Intercept & Yes & Yes & Yes \\
\hline Industry Fixed-effects & Yes & Yes & Yes \\
\hline $\mathrm{N}$ & 1908 & 1908 & 1882 \\
\hline Adjusted-R2 & 0.4096 & - & - \\
\hline $\mathrm{F}(2,1813)$ & 56.5929 & - & - \\
\hline
\end{tabular}

Note. This table reports regression results of an instrumental variable approach. In the first stage, I predict the accumulated volume of news articles during 90 days prior to and ten days following the announcement of share repurchases for each firm using two instrumental variables: advertising and TV news pressure. The instrument, advertising, equals to the total cost of advertising, media, and promotional expenses as reported in the annual Compustat item XAD. I measure advertising expenditures at the end of the year prior to the repurchase announcements. The instrument, TV news pressure, is the cumulative daily Eisensee and Strömberg's (2007) news pressure indices from ten days prior to and ten days following the share repurchase announcements. Eisensee and Strömberg's (2007) define their news pressure index as the median number of minutes that evening news broadcasts of the major U.S. networks (ABC, CBS, NBC, and CNN) devote to the first three news segments in a day. In the second stage, I regress the dollar amount a firm repurchased on the predicted number of news articles and control variable using a Tobit model. I also include firm and year fixed-effects. Table reports marginal effects at the means. Standard errors are in parentheses. ${ }^{*},{ }^{* *}$, and ${ }^{* * *}$ indicate the marginal effect is significantly different from zero at the $10 \%, 5 \%$, and $1 \%$ significant level, respectively.

\section{$5 \cdot 3$ Interactions with mispricing proxies}

Next, I investigate whether companies with low levels of mispricing will repurchase even fewer shares than otherwise, when media coverage increases (hypothesis 2). Table 5 shows the estimated results of equation (2). In this case, I report estimated coefficients and not marginal effects, as before. In non-linear models the marginal effect of the interaction term is meaningless. The problem is that the statistical package does not "know" that the interaction term is the multiplication of two other variables in the same model, so the partial effect of the interaction is calculated as if it could vary partially from the other variables, which is incorrect (Greene, 2012).

As I expect, I find that the effect of media coverage is particularly large among stocks with small mispricing. The coefficients for the interaction terms between the numbers of news articles prior to the announcements and the degree of mispricing are negative and statistically significant for the market value the firms repurchased, both during the first two quarters and during the first year following the 
announcements. These findings suggest that firms with high media coverage repurchase relatively few shares following the announcements, especially when firms have high numbers of institutional owners and high numbers of analysts who are following the firms. These results are consistent with my second hypothesis that predicts that the negative effect of media coverage around the dates of repurchase announcements on the actual repurchase activities will be more important for stocks with small mispricing than otherwise. To restate these findings, the announcements of companies with negligible mispricing that also receive extensive media coverage are likely to be "cheap talk" because these firms do not have much economic incentives (high undervaluation) to use costly signals and actually repurchase shares.

Table 5

Tobit regressions for the decision to repurchase shares after the announcements, with interaction terms

\begin{tabular}{|c|c|c|c|c|}
\hline & \multicolumn{2}{|c|}{$\begin{array}{l}\text { Quarter } t \text { to } \\
\text { quarter } t+1\end{array}$} & \multicolumn{2}{|c|}{$\begin{array}{l}\text { Quarter } t \text { to } \\
\text { quarter } t+3\end{array}$} \\
\hline & (1) & (2) & (3) & (4) \\
\hline \multirow[t]{2}{*}{ News Articles $(-90,10)$} & $0.1105^{* * *}$ & $0.0527^{* *}$ & $0.1530^{* * *}$ & 0.0407 \\
\hline & $(0.0367)$ & $(0.0217)$ & $(0.0583)$ & $(0.0332)$ \\
\hline \multirow[t]{2}{*}{ News Articles $(-90,10)^{*} \operatorname{Ln}(1+$ Intitutions $)$} & $-0.0187^{* * *}$ & & $-0.0267^{* * *}$ & \\
\hline & $(0.0055)$ & & $(0.0087)$ & \\
\hline \multirow[t]{2}{*}{ News Articles $(-90,10) * \operatorname{Ln}(1+$ Analysts $)$} & & $-0.0209^{* * *}$ & & $-0.0199 *$ \\
\hline & & $(0.0069)$ & & $(0.0105)$ \\
\hline \multicolumn{5}{|l|}{ Controls: } \\
\hline \multirow[t]{2}{*}{ Ln (1+Institutions) } & $0.4443^{* *}$ & & $0.6361^{* *}$ & \\
\hline & $(0.2203)$ & & $(0.3238)$ & \\
\hline \multirow[t]{2}{*}{ Ln (1+Analysts) } & & $0.3961^{* * *}$ & & $0.4887^{* *}$ \\
\hline & & $(0.1474)$ & & $(0.2221)$ \\
\hline \multirow[t]{2}{*}{ Cash to Assets } & $2.5467^{* * *}$ & $2.6295^{* * *}$ & $5.6647^{* * *}$ & $5.7960^{* * *}$ \\
\hline & $(0.5936)$ & $(0.5919)$ & $(0.9033)$ & $(0.9043)$ \\
\hline \multirow[t]{2}{*}{ Market-to-Book Ratio } & -0.0208 & -0.0182 & -0.0197 & -0.0178 \\
\hline & $(0.0206)$ & $(0.0208)$ & $(0.0316)$ & $(0.0316)$ \\
\hline \multirow[t]{2}{*}{ Returns Past 12 Months } & $0.5489^{* *}$ & $0.6031^{* * *}$ & $0.9558^{* * *}$ & $1.0395^{* * *}$ \\
\hline & $(0.2160)$ & $(0.2180)$ & $(0.3150)$ & $(0.3175)$ \\
\hline \multirow[t]{2}{*}{ Stock Volatility Past 24 Months } & -2.0003 & -1.9532 & $-5.4900^{*}$ & $-5.3796^{*}$ \\
\hline & $(2.2234)$ & $(2.2319)$ & $(3.1350)$ & $(3.1584)$ \\
\hline \multirow[t]{2}{*}{ Ln (Assets) } & $0.8606^{* * *}$ & $0.9098^{* * *}$ & $1.6042^{* * *}$ & $1.6607^{* * *}$ \\
\hline & $(0.2042)$ & $(0.2056)$ & $(0.3150)$ & $(0.3169)$ \\
\hline \multirow[t]{2}{*}{ Ln (Market Equity) } & $-0.7554^{* * *}$ & $-0.7400^{* * *}$ & $-1.2808^{* * *}$ & $-1.2378^{* * *}$ \\
\hline & $(0.2218)$ & $(0.2057)$ & $(0.3363)$ & $(0.3189)$ \\
\hline \multirow[t]{2}{*}{ Leverage } & -0.2588 & -0.3293 & $-1.7685^{*}$ & $-1.7980^{*}$ \\
\hline & $(0.6013)$ & $(0.6034)$ & $(0.9485)$ & $(0.9467)$ \\
\hline \multirow[t]{2}{*}{$\mathrm{ROA}$} & $5.3912^{* * *}$ & $5.5719^{* * *}$ & $6.5185^{* * *}$ & $6.6752^{* * *}$ \\
\hline & $(1.2413)$ & $(1.2407)$ & $(1.8580)$ & $(1.8579)$ \\
\hline \multirow[t]{2}{*}{ Altman Z-score } & -0.0275 & -0.0313 & $-0.0793^{* *}$ & $-0.0850^{* * *}$ \\
\hline & $(0.0229)$ & $(0.0226)$ & $(0.0322)$ & $(0.0320)$ \\
\hline
\end{tabular}




\begin{tabular}{|c|c|c|c|c|}
\hline & \multicolumn{2}{|c|}{$\begin{array}{l}\text { Quarter } t \text { to } \\
\text { quarter } t+1\end{array}$} & \multicolumn{2}{|c|}{$\begin{array}{l}\text { Quarter } t \text { to } \\
\text { quarter } t+3\end{array}$} \\
\hline & (1) & (2) & (3) & (4) \\
\hline \multirow[t]{2}{*}{ CAPEX to Assets } & 2.5167 & 2.5095 & 3.9588 & 3.8985 \\
\hline & $(2.6227)$ & $(2.6354)$ & $(4.0355)$ & $(4.0428)$ \\
\hline \multirow[t]{2}{*}{ Dividends / Income } & 0.2989 & 0.4572 & $-4.6292^{* *}$ & $-4.5714^{* *}$ \\
\hline & $(1.6141)$ & $(1.6263)$ & $(1.9928)$ & $(2.0221)$ \\
\hline Year Fixed-effects + Intercept & Yes & Yes & Yes & Yes \\
\hline Industry Fixed-effects & Yes & Yes & Yes & Yes \\
\hline $\mathrm{N}$ & 1932 & 1932 & 1906 & 1906 \\
\hline Pseudo-R2 & 0.0219 & 0.0216 & 0.0245 & 0.0238 \\
\hline F Statistic (Prob > F) & $23.69(0.000)$ & $23.79(0.000)$ & $129.51(0.000)$ & $303.03(0.000)$ \\
\hline
\end{tabular}

Note. This table presents the parameter estimates for the following model:

Buyback $_{i}=\alpha+\beta_{1}$ News $_{i}+\beta_{2}$ Mispricings $_{i}+\beta_{3}$ Interactions $_{i}+\gamma^{\prime} X_{i}+T_{i}+I_{i}+\epsilon_{i}$, $^{2}$

where Buyback ${ }_{i}$ as the actual dollar amount firm $i$ repurchased over its market equity, News Articles ${ }_{i}$ is the total number of news articles for firm $i 90$ days prior to and ten days following the announcement. Mispricings $s_{i}$ represents proxies for potential stock mispricing: the number of analysts who follow the stock and the number of institutional owners who hold the stock. Interactions, represents the interaction terms between the number of news articles and the mispricing proxies. The vector $X_{i}$ contains control variables. Firm-level control variables are calculated on a quarterly basis. I define control variables in Appendix. I also include Fama-French 49 industries fixed-effects $\left(I_{i}\right)$ and year fixed-effects $\left(T_{i}\right)$. Table reports marginal effects at the means. Models (1) and (2) consider repurchases in the fiscal quarter of, or the quarter following the announcements. Models (3) and (4) consider repurchases within the first year following the announcements. Table reports estimated coefficients (not marginal effects). Robust standard errors are in parentheses. ${ }^{* * *}$, and ${ }^{* * *}$ indicate the coefficient is significantly different from zero at the $10 \%, 5 \%$, and $1 \%$ significant level, respectively.

\subsection{Investorattention andlong-term returns following buyback announcements}

Finally, a number of studies find that after announcing buybacks, firms over perform in the long run (e.g., Ikenberry, Lakonishok, \& Vermaelen, 1995; Peyer \& Vermaelen, 2008). Yook (2010), however, distinguishes between firms that actually repurchased shares following the announcements and firms that did not. Interesting, Yook finds that only firms that actually repurchased shares experienced significant long-term abnormal returns. In this section, I empirically investigate the relationship between media coverage around the announcement dates and the long-run stock price performances of the announcing firms.

To examine the long-run performances of the announcing firms, I calculate longterm stock returns over different horizons for announcements classified into two categories according to the volumes of news stories around the announcement dates. Table 6 shows the longterm stock price returns for announcing firms with "high" and "low" media coverage according to their volumes of news articles 90 days prior to and ten days following the announcements. To adjust for expected returns, I use multiple approaches. First, I calculate portfolio-matched buy-andhold abnormal returns (BHARs) for three, six, 12 , and 24 months following the announcement dates. Second, I compute cumulative abnormal returns (CARs) over the same horizons. Finally, I use the calendar-time regression approach. In all instances, I show the results for both equallyweighted (EW) and value-weighted (VW) "high" and "low" media coverage portfolios.

Panel A of Table 6 summarizes the BHAR results. I find evidence that the "low" news articles portfolio over performs the "high" news articles portfolio at the three, six, and 12-month intervals for the VW basis. For the EW BHARs, I also find that the "low" news articles portfolio over performs the "high" news articles for the three, six, and 12-month periods, but in contrast to the VW BHARs, these differences are statistically insignificant. Panel B of Table 6 reports CAR results. As with the BHARs approach, I observe 
significant differences for VW CARs at the three, six, and 12-month horizons with the "low" portfolio over performing the "high" media coverage portfolio. Overall, value-weighted BHAR and CAR analyses offer consistent evidence that announcing firms with low volumes of news articles around the announcement dates have higher long-term performances than announcing firms with high volumes of news articles around the announcement dates.

Table 6

Long-term performance for firms with share repurchase announcements

\begin{tabular}{|c|c|c|c|c|c|}
\hline \multicolumn{6}{|c|}{ Panel A: Buy-and-Hold Abnormal Returns (BHARs) } \\
\hline \multirow[b]{2}{*}{ Month } & \multirow{2}{*}{$\begin{array}{c}\text { Media } \\
\text { Coverage }\end{array}$} & \multicolumn{2}{|c|}{ Equal-Weighted } & \multicolumn{2}{|c|}{ Value-Weighted } \\
\hline & & BHARs (\%) & p-value & BHARs (\%) & p-value \\
\hline \multirow[t]{3}{*}{3} & Low & $1.936^{* * *}$ & 0.000 & $0.849^{* *}$ & 0.021 \\
\hline & High & $0.855^{*}$ & 0.058 & $-0.531^{*}$ & 0.069 \\
\hline & Difference & 1.081 & 0.108 & $1.38^{* *}$ & 0.018 \\
\hline \multirow[t]{3}{*}{6} & Low & $3.095^{* * *}$ & 0.000 & $2.06^{* * *}$ & 0.000 \\
\hline & High & $1.763^{* * *}$ & 0.006 & 0.439 & 0.278 \\
\hline & Difference & 1.333 & 0.176 & $1.621^{* *}$ & 0.047 \\
\hline \multirow[t]{3}{*}{12} & Low & $4.375^{* * *}$ & 0.000 & $3.871^{* * *}$ & 0.000 \\
\hline & High & $2.348^{* *}$ & 0.012 & 0.969 & 0.144 \\
\hline & Difference & 2.027 & 0.151 & $2.902^{* *}$ & 0.027 \\
\hline \multirow[t]{3}{*}{24} & Low & $7.514^{* * *}$ & 0.000 & $6.353^{* * *}$ & 0.000 \\
\hline & High & $6.006^{* * *}$ & 0.000 & $3.006^{* * *}$ & 0.005 \\
\hline & Difference & 1.509 & 0.519 & 3.347 & 0.116 \\
\hline \multicolumn{6}{|c|}{ Panel B: Cumulative Abnormal Returns (CARs) } \\
\hline \multirow[b]{2}{*}{ Month } & Media & \multicolumn{2}{|c|}{ Equal-Weighted } & \multicolumn{2}{|c|}{ Value-Weighted } \\
\hline & Coverage & CARs (\%) & p-value & CARs (\%) & p-value \\
\hline \multirow[t]{3}{*}{3} & Low & $1.939^{* * *}$ & 0.000 & $1.118^{* * *}$ & 0.000 \\
\hline & High & $0.937^{* *}$ & 0.039 & $-0.506^{*}$ & 0.091 \\
\hline & Difference & 1.002 & 0.117 & $1.624^{* * *}$ & 0.002 \\
\hline \multirow[t]{3}{*}{6} & Low & $3.181^{* * *}$ & 0.000 & $2.886^{* * *}$ & 0.000 \\
\hline & High & $1.743^{* * *}$ & 0.006 & 0.49 & 0.231 \\
\hline & Difference & 1.438 & 0.116 & $2.396^{* * *}$ & 0.001 \\
\hline \multirow[t]{3}{*}{12} & Low & $4.659^{* * *}$ & 0.000 & $3.916^{* * *}$ & 0.000 \\
\hline & High & $3.021^{* * *}$ & 0.001 & $1.288^{*}$ & 0.053 \\
\hline & Difference & 1.638 & 0.198 & $2.628^{* *}$ & 0.019 \\
\hline \multirow[t]{3}{*}{24} & Low & $7.788^{* * *}$ & 0.000 & $5.843^{* * *}$ & 0.000 \\
\hline & High & $7.876^{* * *}$ & 0.000 & $3.694^{* * *}$ & 0.000 \\
\hline & Difference & -0.088 & 0.960 & 2.149 & 0.177 \\
\hline
\end{tabular}

Note. This table presents long-term stock returns over different horizons for announcing firms classified into two categories according to their levels of media coverage. Panel A presents average compounded buy-and-hold abnormal returns (BHARs) for firms with low (below-median) numbers of news articles 90 days prior to and ten days following the announcements ("low") and firms with high (above-median) numbers of news articles for the same interval of time around the announcement dates ("high"). Returns are compounded three, six, 12, and 24 months after the announcement. I assign firms to matching book-to-market/size portfolios using the quintile breakpoints from Ken French's website. I calculate BHARs by first compounding returns for each firm and then subtracting the compounded return on the matching BM/ME portfolio. I report both equal-weighted (EW) and value-weighted (VW) average returns. For VW returns, I construct the weights using the firm's ME at the beginning of the announcement quarter, scaled by the level of the CRSP VW index at that date. Panel B presents cumulative abnormal returns (CARs) for "low" and "high" media coverage firms. The CARs are similar to the BHARs, except I subtract the matching portfolio return each month and then sum (rather than compound) returns over the cumulating window. ${ }^{*}, * *$, and ${ }^{* * *}$ indicate the coefficient is significantly different from zero at the $10 \%, 5 \%$, and $1 \%$ significant level, respectively. 
Next, I calculate long-run abnormal returns using a calendar-time approach. This approach is as follows: for both the "high" and "low" attention portfolios, for every month from January 2003 to December 2012, I form equal-weighted and value-weighted portfolios of firms that had announced share repurchases in the preceding 12 months, and that belong to the specific attention portfolio ("high" or "low"). Then, I regress the calendar-time returns for these portfolios on the Fama and French (1993) three-factor model and Carhart (1997) four-factor model.

Table 7 presents the post-issue abnormal stock price performances from $(+1,+12)$ months following the announcements for the two portfolios that I classify by the total volume of news articles prior to the announcements. I find evidence of a negative relationship between firm-specific volumes of news articles around the announcement dates and post-issue abnormal returns that is consistent with prior results and support my third hypothesis. Specifically, Panel A of Table 7 shows that when I use the equallyweighted (EW) three-factor model and the fourfactor model, respectively, announcing firms in the "low" portfolio have significantly positive average post-issue abnormal returns (alphas): 0.4 percent per month (4.8 percent after one year) and 0.42 percent per month (5.04 percent after one year). The results are statistically significant at the one percent level. Panel B of Table 7 shows the results when I use the value-weighted (VW) portfolios. Both the three-factor model and the four-factor model yield significantly positive average postissue abnormal returns for announcing firms in the "low" portfolio: 0.23 percent per month (2.76 percent after one year) and 0.25 percent per month (3.0 percent after one year). Furthermore, Table 7 shows that firms in the "high" portfolio have abnormal returns that are not statistically different from zero in any of the models.

\section{Table 7}

\section{Calendar-time factor regressions for firms with share repurchase announcements one-year prior}

\begin{tabular}{|c|c|c|c|c|c|c|c|c|c|c|c|}
\hline \multicolumn{12}{|c|}{ Panel A: Equal-Weighted } \\
\hline \multirow[b]{2}{*}{$\begin{array}{l}\text { Media } \\
\text { Coverage }\end{array}$} & \multicolumn{5}{|c|}{ FF 3 Factor Model } & \multicolumn{6}{|c|}{ CARHART 4 Factor Model } \\
\hline & $\begin{array}{c}\text { Alpha } \\
(\%)\end{array}$ & MKT & SMB & HML & $\begin{array}{l}\text { Adj. } \\
\text { R2 }\end{array}$ & $\begin{array}{c}\text { Alpha } \\
(\%)\end{array}$ & MKT & SMB & HML & UMD & $\begin{array}{l}\text { Adj. } \\
\text { R2 }\end{array}$ \\
\hline Low & $0.4^{* * *}$ & 0.844 & 0.258 & 0.044 & 0.911 & $0.42^{* * *}$ & 0.816 & 0.291 & 0.026 & -0.054 & 0.912 \\
\hline High & $0.14^{*}$ & 0.920 & 0.102 & -0.143 & 0.875 & $0.15^{*}$ & 0.906 & 0.119 & -0.152 & -0.027 & 0.875 \\
\hline \multicolumn{12}{|c|}{ Panel B: Value-Weighted } \\
\hline & \multicolumn{5}{|c|}{ FF 3 Factor Model } & \multicolumn{6}{|c|}{ CARHART 4 Factor Model } \\
\hline $\begin{array}{l}\text { Media } \\
\text { Coverage }\end{array}$ & $\begin{array}{c}\text { Alpha } \\
(\%)\end{array}$ & MKT & SMB & HML & $\begin{array}{l}\text { Adj. } \\
\text { R2 }\end{array}$ & $\begin{array}{c}\text { Alpha } \\
(\%)\end{array}$ & MKT & SMB & HML & UMD & $\begin{array}{l}\text { Adj. } \\
\text { R2 }\end{array}$ \\
\hline Low & $0.23^{*}$ & 0.923 & 0.259 & -0.081 & 0.846 & $0.25^{*}$ & 0.873 & 0.281 & -0.144 & -0.140 & 0.862 \\
\hline High & 0.18 & 0.861 & -0.011 & -0.187 & 0.783 & 0.19 & 0.843 & -0.003 & -0.209 & -0.049 & 0.784 \\
\hline
\end{tabular}

Note. This table reports calendar-time factor regression results of portfolios consisting of firms that announced share repurchases in the prior year and belong to different media attention categories according to the total number of news articles days surrounding the announcements (I consider the number of news articles 90 days prior to and ten days following the announcements). Every month from January 2003 to December 2012, I form equally-weighted (Panel A) and value-weighted (Panel B) portfolios of firms that announced share repurchases in the past year and belong to a specific attention category. The dependent variable is the excess return of the portfolio over one-month T-bill rate. I use the Fama and French (1993) three-factor model and Carhart (1997) four-factor model as our factor models, and measure portfolio underperformance as the intercept $(\alpha)$ from the factor regressions. The upper part of each panel reports results when I classified firms into "high" and "low" investor attention announcements by dividing announcers into above and below-median values for the volume of news articles around the announcement dates. The lower part of each panel reports the results for announcers that belong to a specific media coverage quintile. ${ }^{*},{ }^{* *}$, and ${ }^{* * *}$ indicate the coefficient is significantly different from zero at the $10 \%, 5 \%$, and $1 \%$ significant level, respectively. 
Moreover, Table 7 reports that when I calculate the performance for quintiles that I classify by the total volume of news articles around the announcement dates (Panel B of Table 18), only announcing firms in the lowest three quintiles have significantly positive average post-issue abnormal returns and that the highest two quintiles have abnormal returns that are not statistically different from zero. Overall, these results show that the positive long-term performances of share repurchase announcements are negatively related to the degree of media coverage and investor attention on the announcements. Because I find that the fraction of shares a firm actually repurchases after the announcement is negatively associated with the volume of news articles around the announcement dates, results in this section are consistent with Yook (2010).

\section{Summary and concluding remarks}

In this paper, I have demonstrated how media coverage and investor attention affect open-market share repurchase outcomes. To proxy for investor attention, I use the volume of firm-specific news articles in the Thomson Reuters News Analytics data base, a comprehensive archive of stories that covers thousands of companies in the U.S.

In the context of share repurchase announcements, my results show that investor attention has significant effects on corporate actions. In particular, I find that investor attention, measured by the volume of firm-specific news stories, around the dates of share repurchase announcements is a significant determinant of firms' actual repurchase activities. I also find that limited investor attention may cause market underreaction to the announcements of low media firms, resulting in subsequent positive long-term stock performances for these firms. The bottom line of my analysis is that investor attention and media coverage are significantly related to share repurchase outcomes.
Confounding effects that can simultaneously drive both the volume of news articles around the announcement dates, and share repurchase outcomes may affect my findings. To partially alleviate this concern, I use an instrumental variable approach. The instruments I employ are proxies for exogenous distraction events (measured by sensational media reporting on TV) and firms' advertising expenditures. These instruments represent events that are likely to affect the volume of firm-specific news articles, but that will have no direct effects on share repurchases. After these robustness tests, my results still hold.

Nevertheless, other instruments or other methodologies may be more appropriate. For instance, a potential instrumental variable candidate is the presence of board members with mass media experience (Gurun, 2014). I could also employ alternative methodologies to check the robustness of my results. For example, although I specifically control for a set of firm characteristics that may affect share repurchase actions, an alternative methodology may involve using matching procedures to obtain a closely matched sample of control firms and differencein-difference estimations to ensure that media coverage, and not cross-sectional heterogeneity, is driving the observed share repurchase differences. However, I will leave these additional robustness checks for future research.

Besides the necessity of performing additional checks, this study identifies another important role for investor attention and media coverage on financial markets. More importantly, this paper illuminates the issue of the extent to which companies can effectively use costless signaling to manipulate stock prices in the presence of attentive investors.

\section{References}

Barber, B. and T. Odean. (2008). All that glitters: The effect of attention and news on the buying behavior of individual and institutional investors. The Review of Financial Studies, 21(2), 785-818. 
Bhattacharya, U., \& Jacobsen, S. (2015). The share repurchase announcement puzzle: Theory and evidence. Review of Finance, 19, 1-34.

Bhojraj, S., Hribar, P., Picconi, M., \& McInnis, J. (2009). Making sense of cents: An examination of firms that marginally miss or beat analyst forecasts. The Journal of Finance, 64(5), 2361-2388.

Brav, A., Geczy, C., \& Gompers, P. (2000). Is the abnormal return following equity issues anomalous? Journal of Financial Economics, 56, 209-249.

Cahan, S., Chen, C., \& Nguyen, N. H. (2013). Media sentiment, investor sentiment, and stock price sensitivity to earnings [Working paper]. University of Auckland Business School, Auckland, New Zealand.

Eisensee, T., \& Ströemberg, D. (2007). News droughts, news floods, and U.S. disaster relief. Quarterly Journal of Economics, 122(2), 693-728.

Fang, L., \& Peress, J. (2009). Media coverage and the cross-section of stock returns. The Journal of Finance 4, 2023-2052.

Greene, W. (2012). Econometric analysis (7th ed.). New York: Prentice Hall.

Gurun, U. (2014). Price of Publicity [Working paper]. University of Texas, Dallas, EUA.

Gurun, U., \& Butler, A. (2012). Don't believe the hype: Local media slant, local advertising, and firm value. The Journal of Finance, 67(2), 561-598.

Ikenberry, D., Lakonishok, J., \& Vermaelen, T. (1995). Market underreaction to open market share repurchases. Journal of Financial Economics, 39, 181-208.

King, M. R., \& Segal, D. (2009). The long-term effects of cross-listing, investor recognition, and ownership structure on valuation. Review of Financial Studies, 22(6), 2393-2421.
Kyle, A., Obizhaeva, A., Sinha, N., \& Tuzun, T. (2012). News articles and the invariance hypothesis [AFA 2012 Chicago Meetings Paper]. University of Maryland, Chicago, EUA.

Lehavy, R. \& Sloan, R. (2008). Investor recognition and stock returns. Review of Accounting Studies, 13(2-3), 327-361.

Liu, L., Sherman, A. E., \& Zhang, Y. (2014). The long-run role of the media: Evidence from initial public offerings. Management Science, 60, 1945-1964.

Madsen, J., \& Niessner, M. (2015). Is investor attention for sale? The role of advertising in financial markets [Carlson School of Management Working Paper]. University of Minnesota, EUA.

Mitchell, M., \& Stafford, E. (2000), Managerial decisions and long-term stock price performance. Journal of Business, 73(3), 287-329.

Nguyen, T. (2013). Two essays on stock repurchases-the post repurchase announcement drift: An anomaly in disguise? and intra industry effects of IPOs on stock repurchase decisions. (Ph.D. Thesis). University of South Florida, Florida, USA.

Oded, J. (2005). Why do firms announce open market repurchase programs? Review of Financial Studies, 18(1), 271-300.

Peress. J., \& Schmidt, D. (2014). Glued to the TV: The trading activity of distracted investors [Working Paper Presented at AFA Meetings 2015]. Insead, HEC Paris

Peyer, U., \& Vermaelen, T. (2009). The nature and persistence of buyback anomalies. Review of Financial Studies, 22(4), 1693-1745.

Reuter, J., \& Zitzewitz, E. (2006). Do ads influence editors? Advertising and bias in the financial media. The Quarterly Journal of Economics, 121(1), 197-227. 
Sinha, N. (2010). News articles and momentum. [Working paper], University of Illinois: Chicago.

Stock, J., Wright, J., \& Yogo, M. (2002). A survey of weak instruments and weak identification in generalized method of moments. Journal of Business and Economic Statistics, 20, 518-529.

Tetlock, P. (2007). Giving Content to Investor Sentiment: The Role of Media in the Stock Market. The Journal of Finance, 62(3), 1139-1168.

Tetlock, P., Saar-Tsechansky, M., \& Macskassy, S.(2008). More than words: Quantifying language to measure firms' fundamentals. The Journal of Finance, 63(3), 1437-1467.

Vermaelen, T. (1984). Repurchase tender offers, signaling, and managerial incentives. Journal of Financial and Quantitative Analysis, 19(2), 163-181.

Yook, K. (2010). Long-run stock performance following stock repurchases. Quarterly Review of Economics and Finance, 50(3), 323-331.

Zhuang, C. (2014). Share repurchases: How important is market timing? (Ph.D. Dissertation). University of Southern California, California, USA.

\section{Appendix - Variable definition}

\begin{tabular}{|c|c|}
\hline Variable name & Definition \\
\hline Buyback & $\begin{array}{l}\text { Percentage of actual repurchases, measured by the Compustat item Purchase of Common and } \\
\text { Preferred Stock (PRSTKCY in the Compustat database) minus any decrease in the value of } \\
\text { preferred stocks (at redemption or carrying values, PSTKRQ or PSTKQ items in the Compustat } \\
\text { database, respectively), over market equity the quarter immediately prior to the announcement. }\end{array}$ \\
\hline $\operatorname{CAR}(-1,1)$ & $\begin{array}{l}\text { Cumulative abnormal return over the three-day event window around the announcement date. } \\
\text { The market-adjusted cumulative abnormal return is calculated from market model regressions } \\
\text { for each announcing firm and is subtracted from returns of the firm. The market model } \\
\text { estimation window starts } 250 \text { trading days before the offering and ends five trading days before } \\
\text { the announcements. Firms that have no returns for at least } 30 \text { trading days are dropped. }\end{array}$ \\
\hline News Articles & $\begin{array}{l}\text { Accumulated volume of news articles for the announcing firm } 90 \text { days prior to and ten days } \\
\text { following the announcement. }\end{array}$ \\
\hline ROA & Income Before Extraordinary Items / Total Assets. \\
\hline Altman Z-Score & $\begin{array}{l}\text { Altman_Z }=1.2^{*}(\text { Current Assets } / \text { Total Assets })+1.4^{*}(\text { Retained Earnings } / \text { Total Assets })+ \\
3.3^{*}(\text { Pretax Income } / \text { Total Assets })+0.6^{*}(\text { Market Equity / Total Liabilities })+0.99^{*}(\text { Sales } / \text { Total } \\
\text { Assets }) \text {. }\end{array}$ \\
\hline Cash to Assets & Cash and Short-Term Investments / Total Assets. \\
\hline Market-to-Book Ratio & $\begin{array}{l}\text { Market Equity / Book Value of Equity, } \\
\text { where Market Equity=Price* Common Shares Outstanding, and } \\
\text { Book Equity= Stockholders Equity + Deferred Taxes + Investment Tax Credit - Preferred Stock. }\end{array}$ \\
\hline Return Past 12 Months & Stock Return of Last 12 Months of Fiscal Period. \\
\hline $\begin{array}{l}\text { Stock Volatility Return Past } 24 \\
\text { Months }\end{array}$ & Total Stock Return Volatility in the Last 24 Months. \\
\hline Leverage & (Debt in Current Liabilities + Long-Term Debt) / Total Assets. \\
\hline ROA & Income Before Extraordinary Items / Total Assets. \\
\hline CAPEX to Assets & Capital Expenditures / Total Assets. \\
\hline Tobin's Q & (Total Assets + Market Equity - Book Value of Equity) / Total Assets. \\
\hline Age & Years since IPO. \\
\hline Dividends / Income & Cash Dividends / Income Before Extraordinary Items. \\
\hline
\end{tabular}




\begin{tabular}{ll}
\hline Variable name & Definition \\
\hline Advertising & $\begin{array}{l}\text { Equals to the total cost of advertising, media, and promotional expenses as reported in the } \\
\text { annual Compustat item XAD. I measure advertising expenditures at the end of the year prior to } \\
\text { the repurchase announcements. }\end{array}$ \\
\hline TV News Pressure & $\begin{array}{l}\text { Summation of the daily Eisensee and Strömberg's (2007) indices from ten days prior to and ten } \\
\text { days following the share repurchase announcements. }\end{array}$ \\
\hline Institutional Ownership Ratio & Shares held by institutional investors, as reported on form 13F / Shares Outstanding. \\
\hline
\end{tabular}

\section{Notes}

1 Practitioners generally use the term "share buybacks". In this article, I use "share buyback," "stock buyback," or "share repurchase" interchangeably.

2 Major news outlets, specialized webpages, and financial blogs dedicate large amounts of space to cover share repurchase announcements and the companies involved. The increased attention is partly due to the fact that in the last decade, share repurchase programs have surpassed dividends as a way for companies to return cash to their shareholders (Zhuang, 2014). The financial media have noticed this phenomenon and have regularly covered the announcements of share buybacks. This coverage has been rather negative, and critics tend to focus on the vast amount of resources that firms divert from long-term investments in favor of financial engineering strategies. For example, The Economist has made this point in a series of articles, including "Share Buy-Backs, The Repurchase Revolution" (September 13, 2014). The financial media has also questioned the unfortunate timing of the repurchases. See for example, The Wall Street Journal article titled, "The Downside to Stock Buybacks" (October 25, 2014).

3 To compute CARs and BHARs, I modify the SAS code in the Internet Appendix of Bhojraj, Hribar, Picconi, and McInnis (2009), available at http://www.afajof.org/ details/page/3626901/Supplements.html.

4 In all my tests, I use the total volume of news articles, rather than only news stories related to buybacks.
Although TRNA provides a topic code for each story in the database, this categorization is very broad. In fact, according to TRNA topic codes, most of the news stories (about 33 percent) within the window of -90 to +10 days in my sample relate to performance, results, and earnings (topic code RES). The topic code for buybacks and share repurchases (BUYB) is not very prevalent in my sample. According to topic codes, only $1 \%$ of the news articles appear to be related to buybacks within the window of -90 to +10 days, which is a surprisingly low amount. I conclude that topic codes on TRNA are imprecise, and I prefer not to use them. Furthermore, I believe that, because the purpose of this paper is to use the volume of news articles as a proxy for investor attention, the quantity, and not the topic of the news stories, is the most important factor. The volume of news articles, regardless of their content, has been used in the literature before to proxy for investor attention (e.g., Barber and Odean, 2008; Fang and Peress, 2009; and Liu, Sherman, and Zhang, 2014).

5 As an additional robustness check (unreported), and to mitigate the possibility that my results show bias because overlapping announcements made by the same company (within the window I use to measure actual buyback activity after the announcements), I rerun the main test on Table 3 after excluding 452 announcements made by the same companies within a year of the previous announcements. The results remain robust. (I thank an anonymous referee for this suggestion). 


\section{Supporting agencies:}

For helpful comments, I would like to offer thanks to my advisors James W. McFarland and John M.

Trapani from the A.B. Freeman Business School at Tulane University, and two anonymous referees. I would like to acknowledge the financial support of the Government of Chile and the National Commission for Scientific and Technological Research (CONICYT) through the Bicentennial Becas-Chile Scholarship that allow me to undertake Ph.D. studies.

\section{About the authors:}

Cristian A. Pinto-Gutiérrez, PhD in Finance, Tulane University, USA, Assistant Professor of Finance at Universidad del Desarrollo, Chile. E-mail: cristianpinto@udd.cl.

\section{Contribution of each author:}

1. Definition of research problem

2. Development of hypotheses or research questions (empirical studies)

3. Development of theoretical propositions (theoretical work)

4. Theoretical foundation / Literature review

5. Definition of methodological procedures

6. Data collection

7. Statistical analysis

8. Analysis and interpretation of data

9. Critical revision of the manuscript

10. Manuscript writing

$\sqrt{ }$
$\sqrt{ }$
$\sqrt{ }$
$\sqrt{ }$
$\sqrt{ }$
$\sqrt{ }$
$\sqrt{ }$
$\sqrt{ }$

